International Section

Arch. Esp. Urol., 61, 1 (87-91), 2008

\title{
BLADDER LEIOMYOMA: CASE REPORT
}

\author{
Octavio Castillo', 2, Alejandro Foneron', Gonzalo Vitagliano', Rafael Sánchez-Salas', Manuel \\ Díaz', Marcelo Fajardo' y Carmen Franco ${ }^{3}$.
}

Unidad de Endourología y Laparoscopia Urológica'. Clínica Santa María.

Departamento de Urología². Facultad de Medicina. Universidad de Chile.

Departamento de Anatomía Patológica3. Clínica Santa María. Chile.

Summary.- OBJECTIVE: Leiomyoma is a benign lesion which represents $0,04-0,5 \%$ of bladder tumors. It is more common in females and its peak incidence is between 4 th and 5 th decades. Surgery is the treatment of choice and adequate results have been previously reported.

METHODS: 38 years old male patient who consulted for chronic pelvic pain syndrome. CT scan showed a $2 \mathrm{~cm}$ diameter exophitic lesion at the anterior left lateral bladder wall, which protruded into the perivesical fat. We performed a laparoscopic partial cistectomy locating the tumor and resecting it with simultaneous cystoscopic control, obtaining negative margins. The opera- tive time was 70 minutes with an intraoperative blood loss of $50 \mathrm{ml}$. Postoperative period was uneventful. Final pathology reported: Bladder wall leiomyoma, without mitosis or atypia. Immunohistochemistry was positive for Actine and Vimentine stablishing diagnosis. Cd 117 /ckit) was negative and ruled out a Gastrointestinal Stromal Tumor.

CONCLUSIONS: Leiomyoma is bladder's most common benign non epithelial tumor. It represents 35-46\% of these lesions with a 2:5 male/female ratio. It origins from the smooth muscle bundles and at the urinary tract the most common localizations are kidney and bladder. Clinical presentation depends on tumor size and localization. Ultrasound is the most useful diagnostic tool and the pathological diagnosis is mandatory. Surgery is the treatment of choice and technique depends on tumor size and localization. The laparoscopic approach seems to be an effective alternative in this group of tumors. Prognosis is good and recurrence is rare.

Keywords: Laparoscopy. Bladder leiomyoma.

Partial cystectomy.

Resumen.- OBJETIVO: El leiomioma es una lesión benigna que representa entre el 0,04-0,5\% de los tumores vesicales no editoriales. Es más frecuente en mujeres y su pico de incidencia está entre la $4^{a}$ y $5^{\underline{a}}$ décadas. La cirugía es el tratamiento de elección, habiéndose comunicado previamente resultados adecuados.

MÉTODOS: Paciente varón de 38 años de edad que consultó por síndrome de dolor pélvico crónico. La tomografía axial computarizada mostraba una lesión exofítica de $2 \mathrm{~cm}$. de diámetro en la parte anterior de 
la pared vesical lateral izquierda, que protruía en la grasa perivesical. Realizamos una cistectomía parcial laparoscópica con localización y resección del tumor bajo control con cistoscopia, obteniendo márgenes negativos. El tiempo operatorio fue de 70 minutos con un sangrado estimado de $50 \mathrm{ml}$. El postoperatorio curso sin complicaciones. El estudio anatomopatológico final informó: leiomioma de la pared vesical sin mitosis ni atipias. El estudio inmunohistoquímico fue positivo para actina y vimentina, estableciendo el diagnóstico. El Cd 117 (cKit) fue negativo y descartó un tumor estromal gastrointestinal.

CONCLUSIONES: El leiomioma es el tumor benigno no epitelial más frecuente en la vejiga. Representa entre $35-46 \%$ de estas lesiones con una revelación hombre/ mujer de 2:5. Se origina a partir de los fascículos de músculo liso y en el aparato urinario las localizaciones más frecuente son riñón y vejiga. La presentación clínica depende del tamaño y la localización del tumor. La ecografía es la prueba diagnóstica más útil y el diagnóstico anatomopatológico es obligatorio. La cirugía es el tratamiento de elección, dependiendo la técnica del tamaño y la localización del tumor. El abordaje laparoscópico parece ser una alternativa eficaz en este grupo de tumores. El pronóstico es bueno y la recidiva rara.

Palabras clave: Laparoscopia. Leiomioma vesical. Cistectomía parcial.

\section{INTRODUCTION}

Leiomyoma is a benign non epithelial lesion which represents $0,04-0,5 \%$ of bladder tumors. It is more common in females and its peak incidence is between the $4^{\text {th }}$ and $5^{\text {th }}$ decades of life. It origins from the smooth muscle bundles and therefore it can be found at any organ with this kind of tissue. In the urinary tract the most frequent localizations are kidney and bladder. In the latter, these lesions could be located at any level intramurally. Surgery is the standard treatment and the surgical approach depends on tumor size and localization at the bladder wall. Prognosis is good due to the benign behavior of these lesions. We present the case of a subserosal bladder leiomyoma surgically treated by a combined laparoscopic transperitoneal approach with simultaneous cystoscopic control.

\section{CASE REPORT}

Previously healthy 38 years old male patient, who consulted for a chronic pelvic pain syndrome. CT Scan showed a $2 \mathrm{~cm}$ diameter xophitic lesion at the left anterolateral bladder wall, which protruded to the perivesical fat. (Figure 1).

We decided to perform a laparoscopic partial cistectomy. Using the modifided lithotomy position and after the creation of pneumoperitoneum with the Veress needle we proceeded with trocar positioning. Using a $10 \mathrm{~mm}$ port at the umbilicus level for the endocamera another $10 \mathrm{~mm}$ in the left lower quadrant and two $5 \mathrm{~mm}$, one in the right lower quadrant and one at the umbilicus level in a pararectal position $(\mathrm{Fi}-$ gure 2), we proceeded to dissect the Retzius space to free the bladder with the Harmonic scalpel $\cap$. Once located the lesion protruding from the left anterolateral wall, we proceeded to the resection with aid of simultaneous cistoscopic view, obtaining a wide macroscopic negative margin. Specimen retrieval was acomplished with an Endobag ${ }^{\circledR}$ device and sent to frozen section, which concluded the presence of a benign fusocelular tumor. Bladder closure was done with intracorpereal suture in a two layer fashion with a running 3-0 and 0 vicryl suture. An Hemovac drainage device and a $20 \mathrm{fr}$ urethral catheter were placed at the end of the surgery. The operative room time was 70 minutes with intraperative blood loss of 50 $\mathrm{ml}$.

Postoperatory period was uneventful, retrieving the urethral catheter at the 5th postoperative day. Final pathological report concluded: Bladder wall leiomyoma, without mitosis or atipia. Inmunohistochemistry was positive for Actine and Vimentine stablishing diagnosis. Cd 117 (c-kit) was negative and ruled out a Gastrointestinal Stromal Tumor (Figure 3).

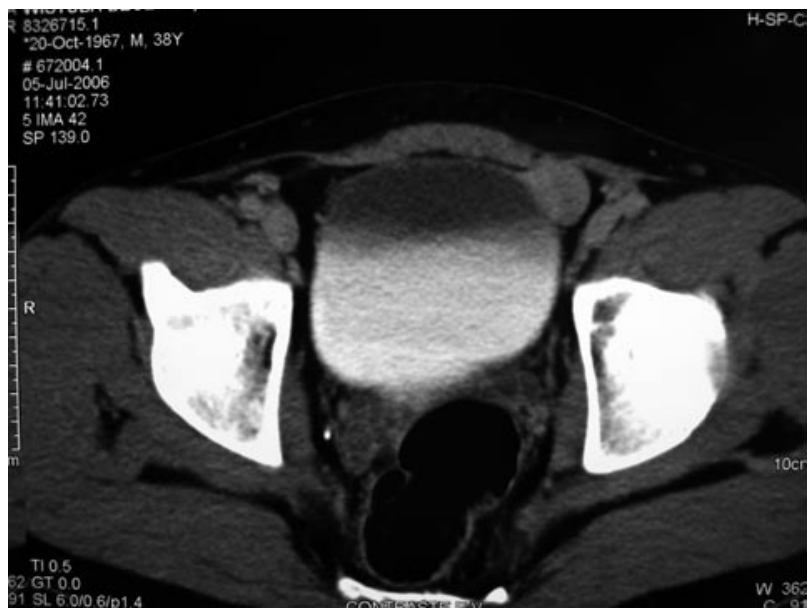

FIGURE 1. Computed tomography showed a $2 \mathrm{~cm}$ diameter exofitic pediculated lesion at the left anterolateral bladder wall, which protruded to the perivesical fat. 


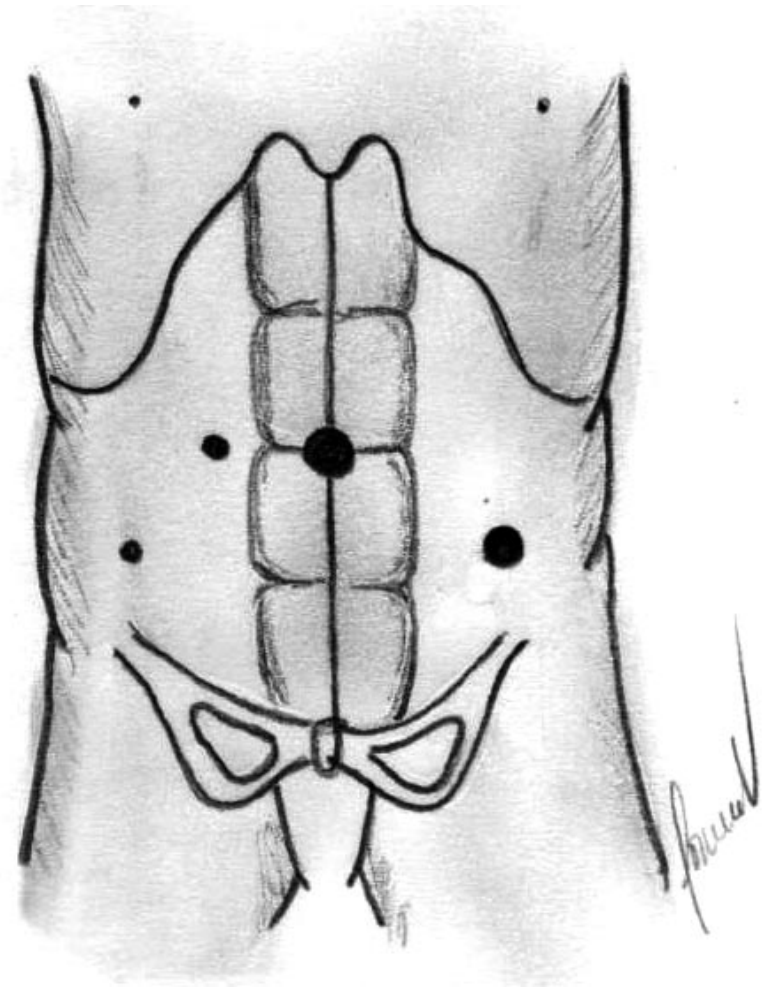

FIGURE 2. Port positioning: A $10 \mathrm{~mm}$ port at the umbilicus level for the endocamera. $10 \mathrm{~mm}$ port in the left lower quadrant and two $5 \mathrm{~mm}$ ports, one in the right lower quadrant and one at the umbilicus level in a pararectal position

\section{DISCUSSION}

Benign non epithelial lesions represent 1$5 \%$ of bladder tumors and Leiomyoma is the most common (1 - 3). It represents $35-46 \%$ of this type of neoplasms and corresponds to $0,04-0,5 \%$ of the bladder lesions in general, with no more than 300 cases reported in the literature (2 - 5). Leiomyoma has its origen from the smooth muscle bundles and contains conective tissue surrounding it. Therefore it can rose in any organ which contains this tissue bieng the most common localizations skin, womb, retroperitoneum, genitourinary and gastrointestinal tract $(1$, $4,6)$. In the genitouri-nary tract it is most frequent in the kidney and bladder, specially at the trigone and bladder neck $(4,6,7)$. It is most common in females in the fertile age, with a female/male ratio $5 / 2$ and its peak incidence between 4th and 5th decades of life $(1,4$ - 6).

The genesis of this lesion remains a mystery; however, there are a bunch of theorys that try to explain this question $(4,8)$ :

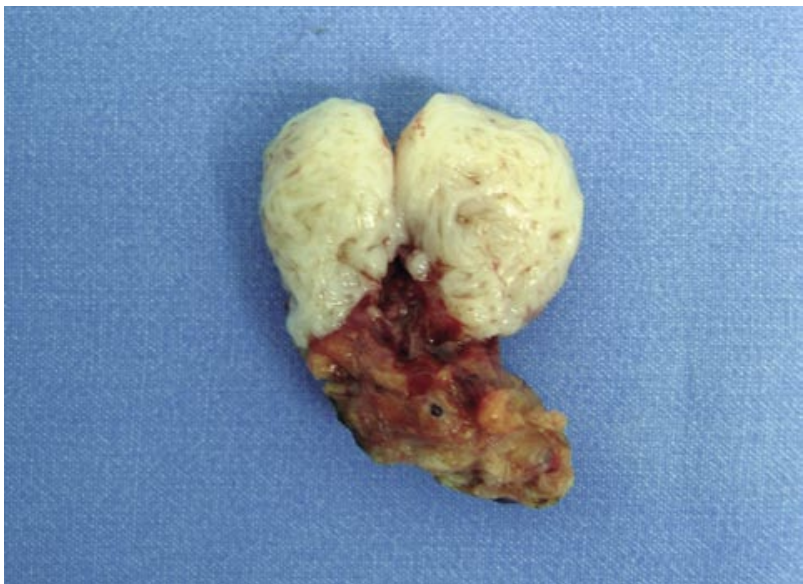

FIGURE 3. Macroscopic appearance of the surgical specimen.

- Blum`s irritative- inflamatory theory, which suggest the presence of a chronic inflamatory stimule over the smoth muscle.

- Piegel's disontogenic theory which suggest its origen from embriogenic rests of Muller and Wolf ducts.

- Vascular-irritative theory

- Lips-Chutz's theory, which suggest its origin secondary to an endocrine disorder with estrogens and progesterone having a primary role. This theory supports its base in the peak incidence in females in the fertile period and the presence of steroidal ovarian receptors on the tumor (9).

Macroscopically these are round or oval tumors with an elastic consistence and irregular surface. The size is variable with reports of tumors as big as $30 \mathrm{~cm}$, specially in the extravesical localization 16 , 7).

In bladder lesions, the localization is submucosal in $63 \%$, and at cistoscopy we can see a sesil or pediculated lesion covered by normal mucosa. The subsesoral localization represents $11-30 \%$ of the cases, having a characteristic pedicle that bounds it with the bladder. The intramural localization is the less frequent and represents $7-17 \%$ of the cases, founding a well encapsulated tumor in the bladder wall $(2,3,6)$ (Table I).

Leiomyomas can remain asymptomatic for many years, reaching considerable size, unless they affect the normal function of the lower urinary tract, (6). Symptoms depend on tumor size and lo- 
TABLE I. LOCALIZATION AT THE BLADDER WALL.

\begin{tabular}{|l|c|c|c|c|}
\hline & Silva-Ramos y cols. (1) & Ojea Calvo y cols. (2) & Jiménez Aristu y cols. (6) & Golobuff et al. (3) \\
\hline Submucosal & $51,1 \%$ & $63 \%$ & $63 \%$ & $66 \%$ \\
\hline Intramural & $30 \%$ & $17 \%$ & $7 \%$ & $3 \%$ \\
\hline Subserosal & $16,7 \%$ & $30 \%$ & $30 \%$ & $11 \%$ \\
\hline
\end{tabular}

calization $(1,7,10)$. Endoluminal tumors are more symptomatic, presenting with urinary tract infections, hematuria, irritative symptoms, specially the ones at the bladder neck, or obstructive symptoms, causing even acute bladder outlet obstruction secondary to a valve effect $(1-3,6,7)$ (Table II). Intramural and subserosal tumors are in general asymptomatic and the diagnosis is incidental. When the size is considerable it can appear as a pelvic mass or give symptoms secondary to the compression of adjacent structures $(6,7)$.
At cistoscopy submucosal tumors appear as a sessile or pediculated lesion covered by normal mucosa, but it could be normal if the tumor is intramural or subserosal. The same situation can occur in the Intravenous Pielography (IVP), showing a filling defect in the bladder wall if the lesion is submucosal. Ultrasound (US) allows to define the solid or cystic nature of the lesion, showing in these cases a solid smooth wall lesion with homogeneous echoes. Also allows to define the limits between the tumor and adjacent structures, showing us its localization in the bladder

TABLE II. PRESENTATION SYMPTOMS.

\begin{tabular}{|l|c|c|}
\hline & Silva-Ramos y cols. (1) & Golobuff et al. (3) \\
\hline Irritative symptoms & $50 \%$ & $38 \%$ \\
\hline Obstructive symptoms & $24,4 \%$ & $49 \%$ \\
\hline Hematuria & $20 \%$ & $11 \%$ \\
\hline Palpable mass & $20 \%$ & $57 \%$ \\
\hline Ureteral obstruction & $6,7 \%$ & $13,5 \%$ \\
\hline Asymptomatic & $26,7 \%$ & $19 \%$ \\
\hline
\end{tabular}


wall. In the case of big tumors we also can see cystic degeneration process. Transvaginal US is an excellent option in female posterior bladder wall tumors in a subserosal localization (3 - 6).

Computed tomography gives us information about the size, position, and relationship between the tumor and bladder wall, but when comparing it with US and Magnetic Resonance Imaging (MRI) its accuracy to define the relationship between the tumor and the bladder wall is inferior $(1,7)$.

Therefore US is considered the most useful imaging diagnostic tool for diagnosis of these tumors $(1,4)$.

MRI shows leiomyoma with an intermediate signal on $\mathrm{Tl}$ weighted images, with good contrast between the tumor and the urine which has a low signal intensity. T2 weighted images shows high and low intensity focis with good contrast between these and the low intensity signals from the bladder wall muscle (3).

Nevertheless imaging tests add important data that suggest the benign nature of these tumors, like the presence of a well circumscribed lesion with homogeneous density, poor enhancement with contrast media and normal perivesical fat. There is no test that allows us to differentiate a leiomyoma from leiomyosarcoma, therefore pathologic diagnosis is mandatory $(1,8)$. Pathological analysis reveals proliferation of smooth muscle fibers with an eosinophilic cytoplasm with less than two mytotic figures per power field. They are sourrounded by a variable amount of conective tissue and there is no necrosis or cellular atypia $(3,8)$. In a literature review by Silva-Ramos et al, 90 bladder leiomyomas where analyzed, 28 of which where biopsied before the definitive treatment. All samples obtained with a Tru-Cut needle and transurethral resection (TUR) where diagnostic, whereas the cold cup biopsy samples showed a $50 \%$ false negative. Fine needle aspiration biopsy was the less useful diagnostic tool (1).

The treatment choice depends on the tumor size and localization and relationship with the bladder wall $(2,10)$. Surgery is indicated because of the potential growing capacity of these tumors (6), however in cases confirmed by biopsy, conservative management is acceptable, keeping in mind that if the tumor increase in size, surgery is mandatory $(3,10)$.

Given the benign nature of these lesions, the surgery must be as conservative as possible. Submucosal tumors can be managed by trans urethral resection, being the size an important issue. Subserosal and huge submucosal lesions can be managed by enucleation or with partial cistectomy. Enucleation via transvaginal approach is a good alternative in tumors close to the urethra, and palpable through the vagina, however the recurrence risk could be higher due to an incomplete resection secondary to the limitations of the operative field $(1,2,10)$.

The laparoscopic approach is an excellent option for tumors located at the mobile wall of the bladder, allowing an easy and safe procedure. Bladder wall edges are simple to identify, specially if simultaneous cistoscopic control is used, which adds the option of resecting the fumor with the resectoscope (10).

Prognosis is good and recurrence is rare if the resection is adequate, therefore it seems not to be necessary to establish follow up protocols. However, Lake in 1981 described what is to date, the only case of a Leiomioma with malignant degeneration $(4,8)$.

\section{REFERENCES AND RECOMENDED READINGS ( of special interest, ${ }^{* *}$ of outstanding interest)}

*1. SILVA-RAMOS, M.; MASSÓ, P.; VERSOS, R. y cols.: "Leiomioma de vejiga. Análisis de agregación de 90 casos". Actas Urol. Esp., 27: 581, 2003.

2. OJEA CALVO, A.; NUÑEZ, A.; ALONSO, A. y cols.: "Leiomioma vesical". Actas Urol. Esp., 25: $759,2001$.

*3. GOLUBOFF, E.; O’TOOLE, K.; SAWCZUK I.: "Leiomyoma of bladder: Report of case and review of literature". Urology, 43: 238, 1994.

4. RUBIO, A.; BONO ARIÑO A.; BERNÉ, J.M. y cols.: "Leiomioma vesical". Arch. Esp. Urol., 53: 934, 2000.

5. YOON, I.J.; KIM, K.H.; LEE, B.H.: "Leiomyoma of the urinary bladder: MR findings". AJR, 161: 449, 1993.

6. JIMÉNEZ, J.; LOZANO, F.; DE PABLO, A. y cols.: "Leiomioma de vejiga. A propósito de un caso". Actas Urol. Esp., 25: 223, 2001.

7. BELIS, J.; POST, G.; ROCHMAN, S. y cols.: "Genitourinary Leiomyomas". Urology, 13: 429, 1979.

8. RODRIGUEZ DE LEDESMA, J.M.; TORROELLA, V.; RAMÍREZ, J. y cols.: "Leiomioma vesical. Revisión de la literatura y presentación de un nuevo caso". Arch. Esp. Urol., 53: 167, 2000.

9. FURUHASHI, M.; SUGANUMA, N.: "Recurrent bladder leiomyoma with ovarian steroid hormone receptors". J. Urol., 167: 1399, 2002.

*10. JESCHKE, K.; WAKONING, J.; WINZELY, M.: "Laparoscopic partial cistectomy for leiomyoma of the bladder wall”. J. Urol., 165: 2115, 2002. 